\section{Non-functioning pituitary adenomas: clinical feature, laboratorial and imaging assessment, therapeutic management and outcome}

\author{
Adenomas hipofisários não-secretores: avaliações clínica, \\ laboratorial, neuro-radiológica e evolução após tratamento
}

Maria Licia Calado de Aguiar Ribeiro Cury', Juliana Coutinho Fernandes ${ }^{1}$, Hélio Rubens Machado², Lucila Leico Elias', Ayrton Custódio Moreira', Margaret de Castro'

\begin{abstract}
Objective: This study is an updated review of a Southeast Brazilian experience NFPA, emphasizing clinical features, laboratorial and imaging assessment, therapeutic management and outcome. Design and Methods: Retrospective study, in which 104 patients with NFPA were evaluated by the same team of endocrinologists and neurosurgeon. Patients underwent biochemical evaluation, radiological studies and visual field assessment. Results: Hypopituitarism and neuro-ophthalmological defects were observed in 89\%. We observed GH deficiency (81.4\%), hypogonadism (63.3\%), adrenal hypofunction (59.5\%), hypothyroidism $(20.4 \%)$, high $(38.5 \%)$ and low $(16.7 \%)$ prolactin levels. Preoperative imaging classified $93 \%$ of the tumors as macroadenomas. Extra-sellar expansion was observed in $83.8 \%$. Varying degrees of visual disturbance were observed in $74 \%$. Primary treatment was transsphenoidal surgery (75\%). Clinical control was achieved with one surgery in $37.5 \%$ of patients. The majority of patients needed a second therapeutic approach, radiotherapy or other surgeries. Immunohistochemistry resulted negative for pituitary hormones in $43 \%$. Improvement of neuro-ophthalmological symptoms was observed in $61 \%$ of the patients after treatment. Conclusions: Our data confirm elevated prevalence of mass effect and hypopituitarism in patients harboring NFPA. Recurrence due to invasion or incomplete resection of the tumor is quite common, which frequently leads to a second therapeutic option. Arq Bras Endocrinol Metab. 2009;53(1):31-39. Keywords
\end{abstract}

Pituitary adenomas; hypopituitarism; neuro-ophthalmological defects; extra-sellar expansion; transsphenoidal surgery

\section{RESUMO}

Objetivos: Esse estudo é uma revisão atualizada em adenomas hipofisários não-secretores (AHNS), enfatizando características clínicas, avaliações laboratorial e neuro-radiológica, manejo terapêutico e desfecho. Métodos: Estudo retrospectivo, em que 104 pacientes com AHNS foram avaliados pela mesma equipe de endocrinologistas e neurocirurgião. Os pacientes foram submetidos à avaliação bioquímica, a estudos radiológicos e à avaliação de campo visual. Resultados: Hipopituitarismo e distúrbios neuro-oftalmológicos foram observados em 89\%. Observou-se deficiência de GH (81,4\%), hipogonadismo (63,3\%), hipofunção adrenal (59,5\%), hipotireoidismo (20,4\%), concentrações elevadas $(38,5 \%)$ e baixas $(16,7 \%)$ de prolactina. Imagens pré-operatórias classificaram os tumores em sua maioria como macroadenomas (93\%). Expansão extra-selar foi observada em $83,8 \%$. Graus variados de distúrbios visuais foram observados em $74 \%$. O tratamento de escolha foi a cirurgia transesfenoidal (75\%). O controle clínico foi alcançado com cirurgia em $37,5 \%$ dos pacientes. A maioria dos pacientes precisou de segunda abordagem terapêutica, radioterapia ou outras cirurgias. A imunoistoquímica resultou negativa para hormônios hipofisários em 43\%. Melhora de sintomas neuro-oftalmológicos foi observada em $61 \%$ dos pacientes após o tratamento. Conclusões: Os dados do estudo confirmam elevada prevalência de efeitos de massa e hipopituitarismo em pacientes com AHNS. Recorrência causada por invasão ou ressecção incompleta do tumor é comum, levando frequentemente à segunda opção terapêutica. Arq Bras Endocrinol Metab. 2009;53(1):31-39.

Descritores

Adenomas hipofisários; hipopituitarismo; defeitos neuro-oftalmológicos; expansão extra-selar; cirurgia transesfenoidal
' Divisão de Endocrinologia e Metabologia do Departamento de Clínica Médica

2 Divisão de Neurocirurgia do Departamento de Anatomia $e$ Cirurgia; Faculdade de Medicina de Ribeirão Preto, Universidade de São Paulo, São Paulo, SP, Brasil

Correspondence to: Margaret de Castro Department of Internal Medicine, School of Medicine of Ribeirao Preto, USP, Av. Bandeirantes, 3900 14049-900 Ribeirao Preto SP castrom@fmrp.usp.br

Received in Aug/8/2008 Accepted in Nov/3/2008 


\section{INTRODUCTION}

Dituitary adenomas are common lesions and repre1 sent 10 to $20 \%$ of all primary brain tumors (1). These tumors can be broadly classified as micro $(<10 \mathrm{~mm}$ diameter) and macroadenomas (>10 mm) and, clinically, as functioning and non-functioning adenomas (NFPA), which do not secrete biologically active pituitary hormones and represent $30 \%$ of all pituitary tumors (2). However, advances in immunoassays, immunohistochemistry, molecular biology techniques and in vitro studies have allowed more detailed characterization of NFPA. Indeed, the majority of clinically NFPA can synthesize intact glycoprotein hormones and/or their free $\alpha$ - and $\beta$-subunits. Therefore, clinically NFPA can actually be considered a diverse group of tumors that also include, besides all these glycoprotein hormones, the null cell adenoma and oncocytoma (1).

According to Kovacs and cols. (3), due to the lack of hypersecretory endocrine signs and symptoms, the diagnosis of NFPA is often delayed and usually presented as a macroadenoma. Clinical manifestations are usually insidious and are represented by endocrinological symptoms, such as hypopituitarism and prolactin hypersecretion, and neurological symptoms due to mass effects. However, because of the increased availability and use of magnetic resonance image (MRI), an increasing number of patients have been incidentally diagnosed as harboring a pituitary adenoma $(4,5)$; about two-thirds of these incidentalomas are microadenomas at diagnosis. Although the NFPA incidentally diagnosed can often be followed conservatively, more than one-third will show significant growth on serial imaging $(6,7)$. On further evaluation, approximately $5 \%$ will have evidence of visual deficits and around $15 \%$ will have some degree of pituitary dysfunction (7), indicating that careful neurological and endocrinological histories are essential in all patients.

Biochemical diagnosis should be followed by a careful screening of the pituitary axis to establish any preoperative endocrine insufficiency. In addition, diagnosis of NFPA preoperatively entails ruling out the secretory syndromes. Pituitary mass must be confirmed by imaging studies (8). Neuro-ophthalmologic tests include fundoscopy, visual field testing and visual acuity.

In the present study, 104 patients harboring NFPA were retrospectively assessed in order to present an updated review of our experience in a primarily tertiary specialist referral center, emphasizing clinical feature, laboratorial and imaging assessment, therapeutic management and outcome.

\section{PATIENTS AND METHODS}

This study was approved by the Ethics Committee for the University Hospital of the School of Medicine of Ribeirao Preto, University of Sao Paulo. We retrospectively reviewed all 104 patients with NFPA followed at the University Hospital between 1990 and 2006. All patients were evaluated by the same team of endocrinologists and operated on by the same neurosurgeon. All patients with NFPA underwent biochemical evaluation to confirm the diagnosis of hypopituitarism, radiological studies of sella turcica by X-ray, computorized tomography (CT) and/or MRI to analyze the mass (size, invasion, relation with optic chiasm) and assessment of visual field.

Cortisol and testosterone levels were measured by radioimmunoassay, as previously reported (9). Free thyroxin $\left(\mathrm{FT}_{4}\right)$ and thyroid stimulating hormone $(\mathrm{TSH})$ were measured by chemiluminescent method (Immulite, DPC Cirrus Inc. Los Angeles, CA). Prolactin (PRL), growth hormone $(\mathrm{GH})$, luteinizing hormone $(\mathrm{LH})$, follicle stimulating hormone (FSH), and estradiol levels were measured by immunofluorometric (IFMA) assays (DELFIA 80/505 Wallac Oy, Turku, Finland). IGF-I levels were measured by immunoradiometric assay (DSL- Diagnostic Systems Laboratories, USA).

Hypothyroidism was diagnosed by basal values of $\mathrm{FT}_{4}$ and TSH according to the normal age-matched values. On the other hand, adrenal, $\mathrm{GH}$, and gonadotrophic deficiencies were confirmed by dynamic tests, when appropriate. To evaluate the adrenal axis we performed the insulin tolerance test (ITT). The GH axis in children was evaluated by two dynamic tests, the ITT and L-dopa tests, after priming with estrogen. Hypogonadism was diagnosed by the gonadotropin releasing hormone $(\mathrm{GnRH})$ test, when patients were in an appropriate chronological and bone age. To confirm vasopressin deficiency, serum sodium, and plasma and urinary osmolality were determined by flame photometry and freezing depression point, respectively. Imaging postoperative follow-up was performed 3 to 4 months and annually until 5 years after surgery. Adenomas' tissues were investigated by immunohistochemichal staining. Demographic data were expressed as mean \pm SD .

\section{RESULTS \\ CLINICAL FEATURES}

One hundred and four patients were assessed $(62 \mathrm{M}$, 42F; 87 Caucasian/ 16 African American/ 1 Asian; mean age was $47.6 \pm 16.1$, ranging between 11-81 
years). Figure 1 shows the distribution of age at diagnosis in patients with clinically NFPA. The follow-up period $(7.4 \pm 5.1)$ ranged from $0-16$ years, median of 6 years. Before diagnosis, duration of symptoms varied from 10 days to 20 years; $95.2 \%$ (99/104) of patients were symptomatic, in $86.9 \%$ the complaints were insidious and in $13.1 \%$ abrupt (less than 30 days of symptomatology). Two patients were asymptomatic $(1.9 \%)$ and in three patients $(2.8 \%)$ this information was not available. Hypopituitarism and neuro-ophthalmological symptoms were observed in 91 patients $(87.5 \%)$; nine patients $(8.6 \%)$ presented only neuro-ophthalmological symptoms while in one patient (1\%) isolated complaints of hypopituitarism were observed (Figure 2).

All clinical manifestations and their frequency are represented in Table 1 . The most frequent clinical manifestations were amenorrhea or menstrual irregularities $(78.6 \%)$, headache $(68.3 \%)$, visual field disturbance $(68.3 \%)$, dizziness $(40.4 \%)$, fatigue or indisposi-

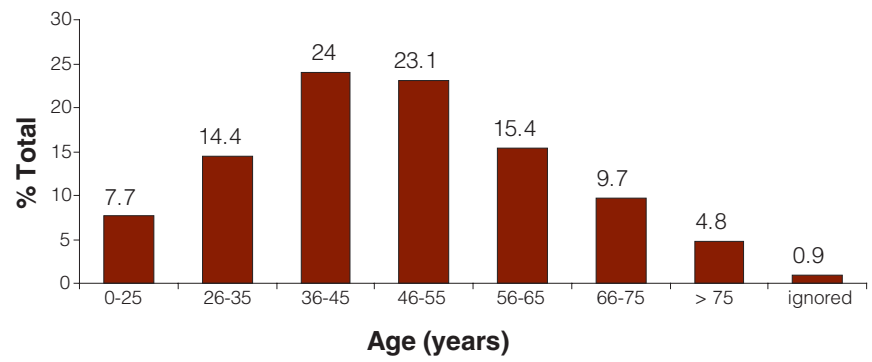

Figure 1. Age at diagnosis in NFPA patients.



Figure 2. Symptoms at diagnosis in NFPA patients. tion $(38.4 \%)$, drowsiness $(35.6 \%)$, erectile dysfunction (33.9\%), dry skin $(30.7 \%)$, diminished libido (29.9\%), nausea/vomiting (29.8\%), constipation $(26.9 \%)$, galactorrhea $(20.2 \%)$ and diabetes insipidus (20.2\%). Four patients presented pituitary adenoma apoplexy symptoms at diagnosis, confirmed by image.

\section{HORMONAL ANALYSIS}

We observed GH deficiency in $81.4 \%$, hypogonadism in $63.3 \%$, adrenal hypofunction in $59.5 \%$, hypothyroidism

\begin{tabular}{lc}
\hline Table 1. Clinical manifestations of NFPA. & \\
\hline Symptoms & Patients (\%) \\
\hline Menstrual irregularities/amenorrhea & 78.6 \\
\hline Headache & 68.3 \\
\hline Visual field disturbance & 68.3 \\
\hline Lack of sexual development & 50.0 \\
\hline Dizziness & 40.4 \\
\hline Fatigue/indisposition & 38.4 \\
\hline Drowsiness & 35.6 \\
\hline Erectile dysfunction & 33.9 \\
\hline Dry skin & 30.7 \\
\hline Diminished libido & 29.9 \\
\hline Nausea/vomiting & 29.8 \\
\hline Constipation & 26.9 \\
\hline Galactorrhea & 20.2 \\
\hline Diabetes insipidus & 20.2 \\
\hline Orthostatic hypotension & 16.3 \\
\hline Weight gain & 16.3 \\
\hline Hair rarefaction & 1.9 \\
\hline Heat/cold intolerance & 15.9 \\
\hline Loss weight & 2.9 \\
\hline Loss of consciousness/coma & 2.9 \\
\hline Diplopia & 11.5 \\
\hline Memory alterations & 11.5 \\
\hline Sleep-wake cycle alterations & 11.5 \\
\hline Ptosis & 10.6 \\
\hline Behavior disturbance & 9.6 \\
\hline Irritability & 7.8 \\
\hline Feeding behavior alterations & 7.7 \\
\hline Paresthesia/tremors & 6.7 \\
\hline Diarrhea & 5.8 \\
\hline Strabismus & 2.9 \\
\hline Pementia & \\
\hline
\end{tabular}


in $20.4 \%$, hyperprolactinemia in $38.5 \%$, and hypoprolactinemia in $16.7 \%$ of the tested patients.

\section{IMAGING FINDINGS}

Radiographic images were performed in 95.2\% (99/104) of individuals before surgery; five patients underwent surgery in other services and images were not available. Until 1995, 7.7\% $(\mathrm{n}=3)$ of the patients were evaluated by X-ray, $84.6 \%$ by CT $(n=33)$ and $7.7 \%(n=3)$ by MRI. Between 1996 and 2000, 38.9\% ( $n=7)$ of the patients were evaluated by CT and $61.1 \%(n=11)$ by MRI; more recently, after $2000,9.5 \%(n=4)$ of the patients were evaluated by CT and $90.5 \%(n=38)$ performed MRI. Based on the available imaging findings, we observed 93\% (92/99) of macroadenomas, $1 \%$ (1/99) of microadenoma, and in $6 \%(6 / 99)$ of the patients classification was not possible, as 3 patients were evaluated only by $\mathrm{X}$-ray and 3 patients underwent MRI in other services and images were not available.

Table 2 shows tumor size and its relationship with extra-sellar expansion and visual field. Tumor sellar localization without expansion was observed in $10.1 \%$ $(10 / 99)$ of the patients. The majority of patients $(83 / 99 ; 83.8 \%)$ presented extra-sellar expansion. Suprasellar expansion was observed in $76 \%(63 / 83)$ of patients; only para-sellar localization in $3.6 \%(3 / 83)$ of patients, and both supra- and para-sellar expansion in $20.5 \%(17 / 83)$.

The most common alterations associated with the presence of the extra-sellar mass were optic chiasmal compression $(41 \%)$, dorsum sellar alterations and/or erosion $(33 \%)$, sphenoid sinus invasion $(16 \%)$, cavernous sinus invasion and/or deformation (12\%). We also observed third ventricle compression $(8 \%)$, infundibulum dislocation (8\%), clinoid invasion (7\%), pituitary apoplexy $(4.8 \%)$, hypothalamus compression (6\%), supra-sellar cistern invasion without chiasmal compression $(6 \%)$, dorsum sellar invasion $(5 \%)$, ventricle dilatation $(2 \%)$, sellar wall destruction $(2 \%)$, and supra-tentorial dilatation $(2 \%)$.

\section{VISUAL FIELD ASSESSMENT}

Visual field was assessed in 94.2\% (98/104) of patients, $26 \%$ were normal and $74 \%$ presented with varying degrees of visual disturbance (Table 2). Six patients had no pre-surgery visual field assessment. Among visual disturbances, $28.8 \%(21 / 73)$ presented bitemporal hemianopsia $(\mathrm{BH}), 19.2 \%(14 / 73)$ uni- or bilateral amaurosis (AM), 13.7\% (10/73) temporal hemianopsia (TH), 13.7\% (10/73) temporal quadrantanopsia (TQ), $8.2 \%(6 / 73)$ defects in the superior field (SF), 6.8\% $(5 / 73)$ temporal and contralateral nasal hemianopsia $(\mathrm{TH}+\mathrm{NH}), 5.5 \%(4 / 73)$ bitemporal hemianopsia and nasal hemianopsia $(\mathrm{BH}+\mathrm{NH}), 2.7 \%(2 / 73)$ nasal quadrantanopsia (NQ), and $1.4 \%(1 / 73)$ defects in the inferior field (IF).

Table 2. NFPA size and its relationship with extra-sellar expansion and visual field.

\begin{tabular}{|c|c|c|c|c|c|}
\hline \multirow{2}{*}{$\begin{array}{l}\begin{array}{l}\text { Size } \\
(\mathrm{mm})\end{array} \\
0-10\end{array}$} & \multirow{2}{*}{$\begin{array}{c}\begin{array}{c}\text { Patients } \\
\text { (\%) }\end{array} \\
1\end{array}$} & \multicolumn{2}{|c|}{$\begin{array}{l}\text { Extra sellar expansion } \\
\qquad(\%)\end{array}$} & \multicolumn{2}{|c|}{$\begin{array}{l}\text { Visual Field } \\
(\%)\end{array}$} \\
\hline & & None & 100 & Normal & 100 \\
\hline $11-20$ & 21.2 & $\begin{array}{l}\text { Supra sellar } \\
\text { None } \\
\text { Para sellar } \\
\text { Both }\end{array}$ & $\begin{array}{c}47.7 \\
42.9 \\
4.7 \\
4.7\end{array}$ & $\begin{array}{c}\text { Normal } \\
\text { TQ } \\
\text { SF } \\
\text { BH } \\
\text { TH } \\
\text { AM }\end{array}$ & $\begin{array}{c}52.4 \\
19 \\
14.8 \\
4.6 \\
4.6 \\
4.6\end{array}$ \\
\hline $21-30$ & 35.3 & $\begin{array}{c}\text { Supra sellar } \\
\text { Para sellar } \\
\text { Both } \\
\text { None }\end{array}$ & $\begin{array}{c}77.2 \\
5.7 \\
17.1 \\
0\end{array}$ & $\begin{array}{c}\text { Normal } \\
\text { TQ } \\
\text { BH } \\
\text { TH } \\
\text { SF } \\
\text { AM } \\
\text { IF } \\
\text { BH+NQ } \\
\text { Unknown }\end{array}$ & $\begin{array}{l}31.4 \\
17.1 \\
14.9 \\
8.6 \\
8.6 \\
5.7 \\
2.9 \\
2.9 \\
8.6\end{array}$ \\
\hline $31-40$ & 19.2 & $\begin{array}{l}\text { Supra sellar } \\
\text { Both } \\
\text { Para sellar } \\
\text { None }\end{array}$ & $\begin{array}{c}73.7 \\
26.3 \\
0 \\
0\end{array}$ & $\begin{array}{c}\mathrm{TH} \\
\mathrm{AM} \\
\mathrm{BH} \\
\mathrm{BH}+\mathrm{NQ} \\
\mathrm{NQ} \\
\mathrm{TH}+\mathrm{NH} \\
\text { Unknown }\end{array}$ & $\begin{array}{c}26.3 \\
26.3 \\
21 \\
10.5 \\
5.3 \\
5.3 \\
5.3\end{array}$ \\
\hline $41-50$ & 13.1 & $\begin{array}{l}\text { Supra sellar } \\
\text { Both } \\
\text { Para sellar } \\
\text { None }\end{array}$ & $\begin{array}{c}69.2 \\
30.8 \\
0 \\
0\end{array}$ & $\begin{array}{c}\mathrm{AM} \\
\mathrm{BH} \\
\mathrm{TH}+\mathrm{NH} \\
\mathrm{HB}+\mathrm{QN} \\
\text { Unknown }\end{array}$ & $\begin{array}{c}30.8 \\
23.1 \\
23.1 \\
7.7 \\
15.3\end{array}$ \\
\hline$>50$ & 4.1 & $\begin{array}{l}\text { Supra sellar } \\
\text { Both } \\
\text { Para sellar } \\
\text { None }\end{array}$ & $\begin{array}{c}75 \\
25 \\
0 \\
0\end{array}$ & $\begin{array}{c}\mathrm{BH} \\
\mathrm{TH}+\mathrm{NH}\end{array}$ & $\begin{array}{l}75 \\
25\end{array}$ \\
\hline Ignored & 6.1 & Unknown & 100 & $\begin{array}{c}\mathrm{BH} \\
\mathrm{AM} \\
\mathrm{TH} \\
\mathrm{TQ} \\
\mathrm{BH}+\mathrm{NQ}\end{array}$ & $\begin{array}{l}33.4 \\
16.7 \\
16.7 \\
16.7 \\
16.7\end{array}$ \\
\hline
\end{tabular}

$\mathrm{BH}=$ bilateral hemianopsia; $\mathrm{AM}=$ amaurosis; $\mathrm{TH}=$ temporal hemianopsia; $\mathrm{TH}+\mathrm{NH}=$ temporal hemianopsia and nasal hemianopsia; $\mathrm{BH}+\mathrm{NQ}=$ bitemporal hemianopsia and nasal quadrantanopsia; $\mathrm{TQ}=$ temporal quadrantanopsia; $\mathrm{NQ}$ = nasal quadrantanopsia; $\mathrm{SF}=$ superior field disturbance; $\mathrm{IF}=$ inferior field disturbance. 
Figure 3 shows the relationship between tumor size and percentage of visual disturbance. We observed visual impairment in $60 \%$ and $95 \%$ of patients presenting tumors larger than 20 and $30 \mathrm{~mm}$, respectively.

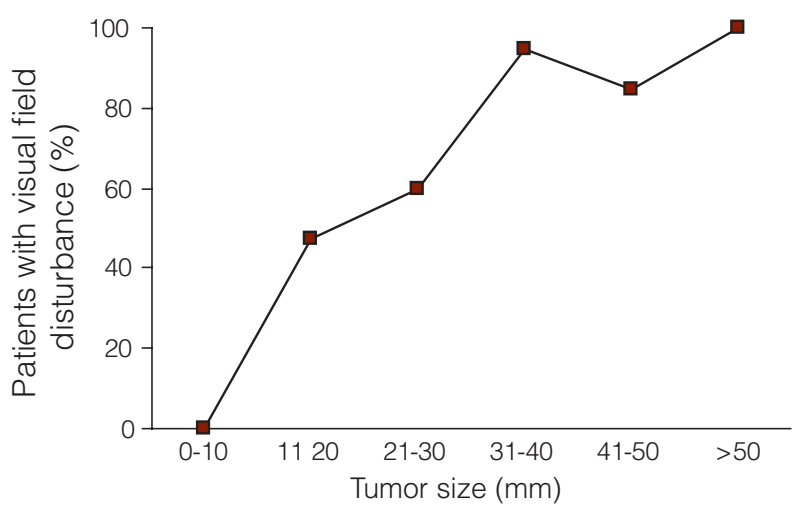

Figure 3. Relationship between tumor size and percentage of visual disturbance.

\section{TREATMENT AND OUTCOME}

The first choice treatment was neurosurgery performed in $83 \%(86 / 104)$ of the patients. Clinical follow-up was the treatment choice in $13(12.5 \%)$ patients. About 1\% was submitted to isolated radiotherapy (RTX) and $3.8 \%$ refused to be treated (Figure 4).

Regarding $13(12.5 \%)$ patients with clinical follow-up, $71.4 \%$ received hormonal replacement, improving hypopituitarism symptoms. Forty six percent presented normal visual field, 38.5\% had a slight loss in visual field, and $15.4 \%$ an important loss in visual field; this group had no surgery due to several associated morbidities. No worsening in neuro- ophthalmological symptoms as well as no tumor growth was observed during 6.9 years of follow-up in these patients.

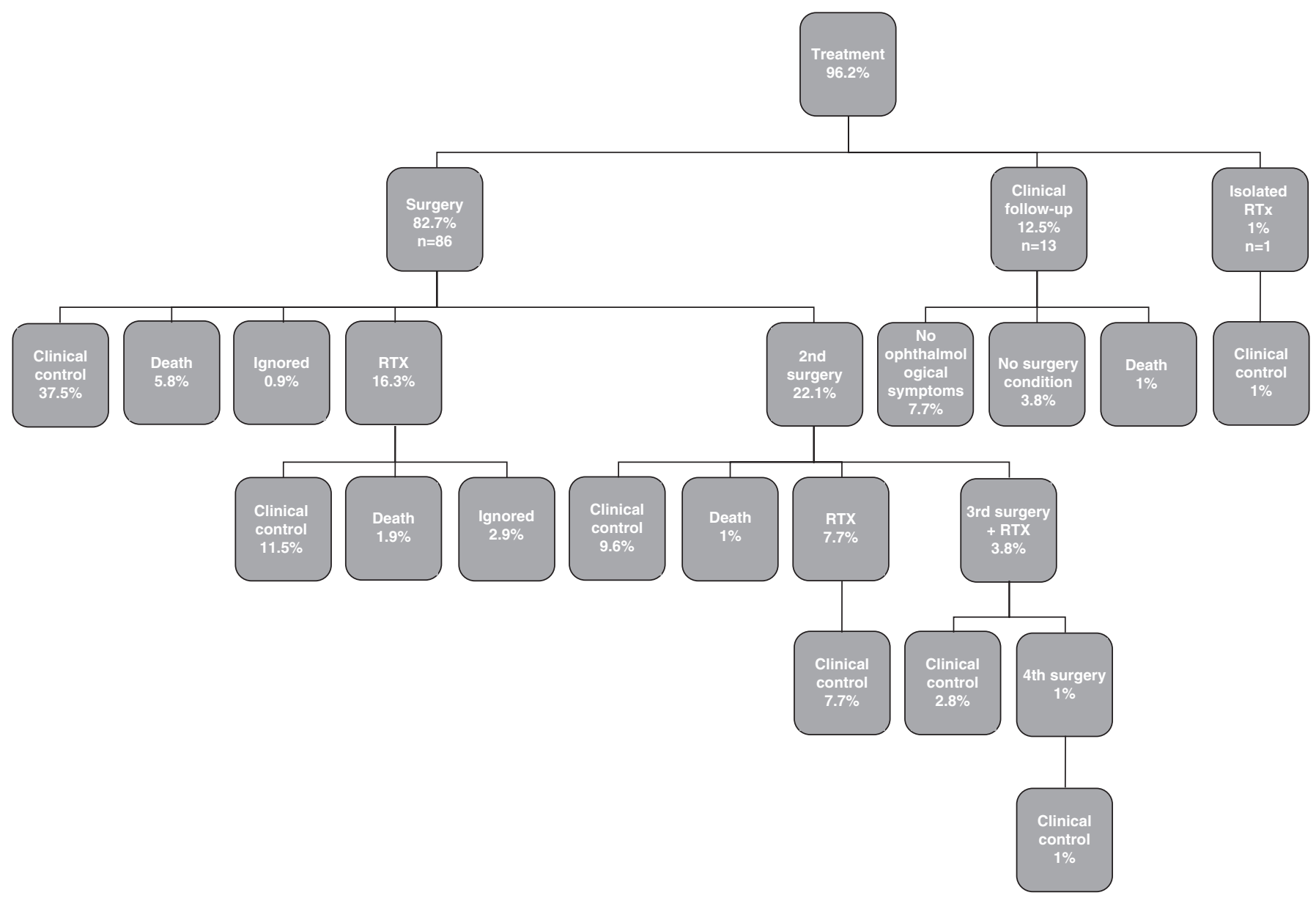

Figure 4. Treatment and outcome of 104 NFPA patients. 
The transsphenoidal route was performed in $90.7 \%$ of surgical cases, while the remaining patients $(9.3 \%)$ were treated by the transcranial approach; $33.7 \%$ of operated patients received adjuvant RTX, indicated due to tumor growth. Clinical control was defined as improvement of clinical manifestations and complete resection or stabilization of the lesion on neuroradiological imaging after 5 years of the surgery, and was achieved in $37.5 \%$ of patients after one surgery. However, many patients underwent more than one therapeutic approach. One surgery and adjuvant RTX were performed in $16.3 \%$ of the cases; a second surgery in $10.6 \%$ and a second surgery with adjuvant RTX in 7.7\%; a third surgery and RTX in $2.8 \%$ and a fourth surgery and RTX in $1 \%$ of the patients. RTX was indicated during the follow-up period after evidence of tumor progression or recurrence.

The most common transsphenoidal surgical complication was diabetes insipidus (8.6\%). Other transsphenoidal surgical complications observed were: cerebrospinal fluid leakage $(6.7 \%)$, ventricular peritoneal derivation $(4.8 \%)$, meningitis $(4.8 \%)$, sinusitis $(3.8 \%)$, hydrocephalus $(2.9 \%)$, confusional state $(2.9 \%)$, anterior hypopituitarism $(2.3 \%)$, ischemic cerebrovascular accident (1.9\%), and subarachnoid haemorrhage, seizures, cistern haemorrhage, ventriculitis and coma in less than $1 \%$, each. Five patients (4.8\%) died in the immediate post-operative period and the causes were subarachnoid haemorrhage and accentuated hydrocephalus; ventriculitis; meningitis; septic shock; hyperglycemic coma and upper digestive tract haemorrhage. One patient died in the late post-operative period from chronic hydrocephalus.

With regard to hormonal replacement in patients with hypopituitarism symptoms diagnosed prior to surgical treatment, $70.3 \%$ continued receiving hormone replacement (35.9\% replaced 1 hormonal axis; $34.4 \%, 2$ axes; and $29.7 \%$, 3 or more axes); only $19.8 \%$ improved after surgical treatment and did not need hormone replacement. Sixty one percent of the patients experienced improvement of neuroophthalmological symptoms after surgical treatment; $10 \%$ experienced worsening; in $15 \%$ symptoms remained without alterations; in $9 \%$ of the patients the outcome could not be evaluated; and $4.8 \%$ died from acute complications.

Regarding the type of primary or adjuvant RTX, 61.5\% were conventional, $26.9 \%$ conformal RTX, and $11.5 \%$ radiosurgery. Doses of conventional RTX used were 4500 rads. Complications were observed mainly in patients who underwent conventional RTX: cognitive and behavior dysfunctions $(22.3 \%)$ - such as forgetfulness, mental confusion, drowsiness and dementia; tumor necrosis (16.7\%); optic nerve atrophy (11.2\%); anterior hypopituitarism (5.5\%); cerebral atrophy (5.5\%); Parkinson Syndrome (5.5\%), and hearing disturbance (5.5\%). Conformal RTX showed 25\% $(\mathrm{n}=2)$ of cognitive and behavior dysfunctions. So far, no complications have been observed on the small number of patients $(n=3)$ who underwent radiosurgery.

During the follow-up period of 16 years, 6 patients died from other co-morbidities, such as breast cancer ( 1 ), heart failure (1), and pneumonia (2). In two patients the cause of death was not available, since patients did not die at our service.

\section{ANATOMOPATHOLOGY AND IMMUNOHISTOCHEMISTRY}

Anatomopathological studies showed in $96.5 \%$ of the samples, alterations suggestive of tumors, and in 3.6\% normal pituitary tissue. The analysis of the tissue also showed $9.5 \%$ of haemorrhagic areas, $8.4 \%$ of necrosis areas, $1.2 \%$ of calcification areas, $1.2 \%$ of cholesterol crystals areas, $1.2 \%$ of cystic areas, and $1.2 \%$ of inflammatory process.

Immunohistochemistry resulted negative to $\mathrm{GH}, \mathrm{LH}$, FSH, PRL, ACTH, TSH in $43 \%$ of the tested pituitary tissues. Among tumors which were immunopositive for anterior pituitary hormones, we observed mainly glycoprotein hormone staining (Table 3 ). It is important to point out that we also observed $9.6 \%$ of immunopositivity for ACTH. There was no association with immunohistochemistry and need of a more aggressive treatment, immediate post operative complications or death. All these parameters were evaluated during a minimal follow-up period of 4.5 years.

\begin{tabular}{lc}
\hline Table 3. Immunohistochemistry of NFPA. & \\
\hline Immuno-staining & Tumors (\%) \\
\hline Negative & 43 \\
LH & 8 \\
FSH & 6.7 \\
PRL & 5.4 \\
TSH & 5.4 \\
GH & 1.4 \\
ACTH & 1.4 \\
LH / TSH & 5.4 \\
LH / FSH & 2.7 \\
LH / PRL & 1.4 \\
ACTH / TSH & 1.4 \\
ACTH / GH & 1.4 \\
ACTH / PRL & 1.4 \\
TSH / PRL & 1.4 \\
TSH / FSH & 1.4 \\
TSH / LH / PRL & 2.7 \\
TSH / LH / FSH & 1.4 \\
TSH / LH / ACTH & 1.4 \\
PRL / FSH / LH & 1.4 \\
PRL / FSH / ACTH & 1.4 \\
TSH / LH / FSH / GH & 1.4 \\
TSH / LH / PRL / ACTH & 1.4 \\
\hline
\end{tabular}




\section{DISCUSSION}

The relatively low annual incidence of pituitary adenoma diagnosis and long natural history of these tumors have hampered efforts to evaluate remote clinical outcomes in a significant number of patients. Recently, reports from Europe (10) and US (11) have developed an evidence-based computerized database, collecting pituitary tumor registry to define features of prognostic significance in patients with NFPA. In the present study, in order to contribute to the improvement of management of these tumors, we show our experience on clinical, biochemical, radiological, ophthalmological features, treatment and outcome of Brazilian patients with NFPA. Data were collected from a primarily tertiary specialist referral center, located in Sao Paulo State, in the Southeast region of Brazil. Analysis of our data indicated NFPA diagnosis was significantly more frequent in men, and almost every patient harbored macroadenomas, in accordance to many reports $(10,12,13)$. NFPA were mainly diagnosed in the late forties, consistent with the pituitary tumor registry in the US (11), but partially in contrast to the Italian database (10), which shows that NFPA were mainly diagnosed between the fifth and the seventh decade. Moreover, $95 \%$ of patients were symptomatic, mainly with insidious complaints, and hypopituitarism and neuro-ophthalmological symptoms were observed in $89 \%$ of the patients. The three main clinical manifestations were hypogonadism, $78 \%$ in women and $35 \%$ in men, headache in $68 \%$ of the patients and visual field disturbance in $68 \%$ of the patients. In the Italian database (10), as well as in the US registry (11), about half of the patients presented with mass-related symptoms, such as visual defects, headache, and hypogonadism symptoms. As suggested by these authors, the signs might still be underestimated or not correctly diagnosed and continue to represent a challenge for endocrinologists, gynecologists, andrologists, ophthalmologists, and, particularly, for general practitioners. The findings in this Brazilian series indicate that prevalence of symptoms at diagnosis is larger than in the Italian and US series, suggesting that the delay between symptom onset and diagnosis is even greater in Brazil, a developing country.

Our data also show GH deficiency, hypogonadism and adrenal hypofunction in the majority of tested patients. We observed almost $40 \%$ of hyperprolactinemia related to stalk deafferentation, which is in agreement to the frequency reported $(42-65 \%)$ in other studies $(10,11,14)$. One fifth of the patients presented with hypothyroidism, consistent with the Italian experience and other studies $(10,15,16)$ and hypoprolactinemia was observed in $16.7 \%$ of the patients. Of particular importance is the detection of cortisol deficiency before thyroid deficiency treatment; failure to establish this diagnosis preoperatively can have dire consequences.

Macroadenomas with extra-sellar expansion were present in the majority of patients at diagnosis, mainly as supra-sellar invasion. Due to no clinical hypersecretory syndrome of NFPA, patients usually present a large mass at diagnosis; MRI is necessary not only for a good delineation of the size and extension of these tumors but also to demonstrate residual tumor and tumor regrowth, situations in which post-operative radiotherapy could be an indication $(17,18)$.

Visual field alterations were observed in the majority of patients (74\%) and showed a wide spectrum of defects, while chiasmal compression on imaging was observed only in $41 \%$ of patients. This discrepancy can be ascribed by the poor quality of imaging in the 90's. The classical bi-temporal field defect was the most common presentation in our study, followed by uni- or bilateral amaurosis. Fields with no typical diagnostic pattern were seen in nearly one tenth of the patients. These data are partially in contrast to an Indian prospective study (19), which showed atypical visual field pattern in $20 \%$ of the patients. In other series, such no typical field constitutes $4.7 \%$ of the cases $(20)$.

In our series, the first choice treatment was neurosurgery $(83 \%)$; transsphenoidal route was performed in $90.7 \%$ of the surgical cases, while the remaining patients were treated by the transcranial approach. Clinical control, defined as improvement of clinical manifestations and complete resection or stabilization of the lesion on neuroradiological imaging, was achieved in $37.5 \%$ of the patients after one surgery. Indeed, our results related to the success of surgery treatment are similar to others' results $(10,11)$, suggesting that surgery in NFPA is almost never curative, probably due to advanced tumor expansion and invasion of neighboring structures. In the absence of good serum markers for residual tumor, the decision on further intervention relies mainly on sequential postoperative imaging (21). Since residual cells retain their inherent ability to proliferate, some tumors continue growing; thus, the indication of a second therapeutic option is usually necessary. One fifth of the patients in the present study underwent a second surgery and another fifth were submitted to adjuvant RTX. In exceptional situations, a third or even fourth surgery associated to RTX was performed in order to achieve clinical control.

The failure of surgical treatment lead to frequent indication for RTX that was performed in more than one third 
of the patients in our series. However, the role of RTX in pituitary tumor management remains controversial. Although its efficacy remnants, in particular, if administered during postoperative period $(12,13,22)$, it has been clearly demonstrated that RTX may cause several side effects (23$25)$. In accordance to these findings, our series showed high percentage of complications after usual doses of conventional RTX, due to the size of tumors and also probably to management of conventional RTX. We observed worsening of anterior hypopituitarism in almost one third of the patients who underwent surgery and adjuvant RTX, cognitive and behavior dysfunctions in one fourth, tumor necrosis in one fifth, besides other lesions in the central nervous system. New radiation techniques, such as Gamma Knife radiosurgery, have shown good efficacy in controlling tumor growth and a more favorable profile of side effects than the conventional fractionated RTX $(26,27)$. In this Brazilian series, few patients underwent radiosurgery, with no observed important side effects. It is important to point out that the radiosurgery technique is supported by insufficient data, due to short-term follow-up studies $(26,27)$.

Because hypopituitarism was an important finding at the diagnosis of NFPA in our series (almost 90\%), persistent diabetes insipidus and hypopituitarism occurred as a treatment complication only in $8.6 \%$ and $3.5 \%$ respectively, which were smaller than the prevalence observed in the US registry (11) - 32\% and 12\%, respectively. With regard to hormonal replacement in patients with hypopituitarism symptoms diagnosed prior to surgical treatment, the majority continued receiving hormone replacement, but one fifth of the patients improved after surgical treatment and did not need hormone replacement. Indeed, this finding reinforces data only recently reported that impaired pituitary function could be restored and could even be normalized or improved by selective surgical resection of the adenomas in $30 \%$ of cases $(28,29)$.

Post-surgical improvement in visual field defects occurred in $61 \%$ of the cases. These results are similar to other series $(30,31)$, but studies have described visual field improvement even in $80 \%$ of the cases (32); the extent of visual impairment recovery is mainly dependent on the preoperative visual deficit, which emphasizes the need for early intervention in these patients.

Regarding mortality in the immediate post-operative period, our series indicate a total rate of $4.8 \%$, in accordance with other studies $(33,34)$. However, better patient outcome after transsphenoidal pituitary tumor surgery, about $1 \%$ or less of death, has been demonstrated in modern series $(35,36)$. It is important to point out that, among the five immediate post-operative deaths, 3 patients harbored giant adenomas (diameter equal to or greater than $50 \mathrm{~mm}$ ). However, in the present study, only one patient died in the immediate post-operative period from complications inherent to surgery; other deaths occurred mainly due to infectious causes (ventriculitis; meningitis; septic shock) or metabolic disturbances. Therefore, our data reflect results from a specialized practice setting, in a developing country where all transsphenoidal pituitary surgeries were performed by only one specialist surgeon (37).

Immunostaining of NFPA may be negative for any pituitary hormone. Alternatively, according to Wilson and cols. (38), NFPA may be positive for various anterior pituitary hormones, most commonly a subunit - $\beta$-FSH, $\beta-\mathrm{LH}$ or $\beta-\mathrm{HCG}$ or less frequently ACTH, TSH, GH or PRL. Turner and cols. ( ${ }^{12)}$ observed $35.4 \%$ of 65 NFPA were gonadotrophin immunopositive and $29.2 \%$ were immunonegative for all pituitary hormones. Our data, in accordance to this study, showed that $43 \%$ of tumors were immunonegative and more than one fourth were positive for gonadotrophin. It is important to point out that, in our series, almost $10 \%$ of NFPA showed immunoreactivity for ACTH, similar to previous data (12). Other studies suggested that NFPA immunopositive for ACTH do not recur more often than ACTH immunonegative; however, when they regrow they show a more aggressive course $(39,40)$.

In conclusion, data collected in this Brazilian series give a complete overview of patients with NFPA, concerning clinical features, therapeutic approaches, and long term outcomes. This study demonstrates the need to reduce the delay between symptom onset and diagnosis of NFPA in a developing country. Our data as well as the US and Italian studies, confirm that predictors of pituitary tumor recurrence and markers of persistent disease activity still have to be identified in order to improve therapeutic guidelines and overall cost-effectiveness in the long-term management of NFPA.

Disclosure: No potential conflict of interest to this article was reported.

\section{REFERENCES}

1. Laws ER, Ebersold MJ, Piepgras DG, et al. The results of transsphenoidal surgery in specific clinical entities. In: Laws ER, Randall RV, Kern EB, et al. Management of Pituitary Adenomas and Related Lesions with Emphasis on Transsphenoidal Microsurgery. New York: AppletonCentury- Crofts, 1982: 277-305.

2. Milker-Zabel S, Debus J, Thilmann C, Schlegel W, Wannenmacher M. Fractionated stereotactically guided radiotherapy and radiosurgery in the treatment of functional and nonfunctional adenomas of the pituitary gland. Int J Radiat Oncol Biol Phys. 2001;50:1279-86.

3. Kovacs K, Scheithauer BW, Horvath E, Lloyd RV. The World Health Organization classification of adenohypophysial neoplasms. A proposed five-tier scheme. Cancer. 1996;78:502-10. 
4. Ebersold MJ, Quast LM, Laws ER, Scheithauer B, Randall RV. Longterm results in transsphenoidal removal of nonfunctioning pituitary adenomas. J Neurosurg. 1986;64:713-9.

5. Scheithauer BW, Kovacs KT, Laws ER Jr., Randall RV. Pathology of invasive pituitary tumors with special reference to functional classification. J Neurosurg. 1986;65(6):733-44.

6. Molitch ME, Russell EJ. The pituitary "incidentaloma". Ann Intern Med. 1990;112:925-31.

7. Feldkamp J, Santen R, Harms E, Aulich A, Modder UM, Scherbaum WA. Incidentally discovered pituitary lesions: high frequency of macroadenomas and hormone-secreting adenomas - results of a prospective study. Clin Endocrinol Oxf. 1999;51:109-13.

8. Klibanski A, Zervas NT. Diagnosis and management of hormone-secreting pituitary adenomas. N Eng J Med. 1991;324:822-31.

9. Castro M, Elias PC, Quidute AR, Halah FP, Moreira AC. Out-patient screening for Cushing's syndrome: the sensitivity of the combination of circadian rhythm and overnight dexamethasone suppression salivary cortisol tests. J Clin Endocrinol Metab. 1999;84:878-82.

10. Ferrante $E$, Ferraroni M, Castrignanò T, Menicatti L, Anagni M, Reimondo $G$, et al. Non-functioning pituitary adenoma database: a useful resource to improve the clinical management of pituitary tumors. Eur J Endocrinol. 2006;155:823-9.

11. Drange MR, Fram NR, Herman-Bonert V, Melmed S. Pituitary tumour registry: a novel clinical resource. J Clin Endocrinol Metab. 2000;85:168-74.

12. Turner HE, Stratton IM, Byrne JV, Adams CB, Wass JA. Audit of selected patients with nonfunctioning pituitary adenomas treated without irradiation - a follow-up study. Clin Endocrinol. 1999;51:281-4.

13. Gittoes NJ, Bates AS, Tse W, Bullivant B, Sheppard MC, Clayton RN Stewart PM. Radiotherapy for non-function pituitary tumours. Clin Endocrinol. 1998;48:331-7.

14. Molitch ME. Natural history and diagnosis of clinically non-functioning adenomas. In: Webb SM, editor. Pituitary tumours: epidemiology, pathogenesis, and management. Bristol: BioScientifica. 1998. p.15-27.

15. Bates AS, Bullivant B, Sheppard MC, Stewart PM. Life expectancy following surgery for pituitary tumours. Clin Endocrinol. 1999;50: 315-9.

16. Greenman Y, Ouaknine G, Veshchev I, Reider-Groswasser II, Segev Y, Stem N. Postoperative surveillance of clinically nonfunctioning pituitary macroadenomas: markers of tumour quiescence and regrowth. Clin Endocrinol. 2003;58:763-9.

17. Soto-Ares G, Cortet-Rudelli C, Assaker R, Boulinguez A, Dubest C, Dewailly D, Pruvo JP. MRI protocol technique in the optimal therapeutic strategy of non-functioning pituitary adenomas. Eur J Endocrinol. 2002;146:179-86.

18. teiner E, Math G, Knospt E, Mostbeck G, Kramer J, Herold CJ. MRAppearance of the Pituitary Gland before and after resection of pituitary macroadenomas. Clinical Radiol. 1994;49:524-30.

19. Thomas R, Shenoy K, Seshadri MS, Muliyil J, Rao A, Paul P. Visual field defects in non-functioning pituitary adenomas. Indian J Ophthalmol. 2002;50:127-30.

20. Ramamurthy G. Experience with large pituitary adenomas in India. Neurology India. 1986;34:195-201.

21. Greenman Y, Tordjman K, Kisch E, Razon N, Ouaknine G, Stern N. Relative sparing of anterior pituitary function in patients with growth hormone- secreting macroadenomas: comparison with nonfunctioning macroadenomas. J Clin Endocrinol Metab. 1995;80:1577-83.
22. Gittoes NJ. Radiotherapy for non-functioning pituitary tumours- when and under what circumstances? Pituitary. 2003;6:103-8.

23. McCord MW, Buatti JM, Fennell EM, Mendenhall WM, Marcus RB Jr, Rhoton $\mathrm{AL}$, et al. Radiotherapy for pituitary adenoma: long-term outcome and sequelae. Int J Radiat Oncol Biol Phys. 1997;39:437-44.

24. Littley MD, Shalet SM, Beardwell CG, Ahmed SR, Applegate G, Sutton ML. Hypopituitarism following external radiotherapy for pituitary tumours in adults. Q J Med. 1989;70:145-60.

25. Brada M, Ford D, Ashley S, Bliss JM, Crowley S, Mason M, Rajan B, Traish D. Risk of second brain tumour after conservative surgery and radiotherapy for pituitary adenoma. Br Med J. 1992;23:1343-6.

26. Sheehan JP, Kondziolka D, Flickinger J, Lunsford LD. Radiosurgery for residual or recurrent nonfunctioning pituitary adenoma. J Neurosurg. 2002;97:408-14.

27. Losa M, Valle M, Mortini P, Franzin A, da Passano CF, Cenzato M, et al. Gamma knife surgery for treatment of residual nonfunctioning pituitary adenomas after surgical debulking. J Neurosurg. 2004;100:438-44.

28. Arafah BM, Brodkey JS, Manni A, Velasco ME, Kaufman B, Pearson OH. Recovery of pituitary function following surgical removal of large nonfunctioning pituitary adenomas. Clin Endocrinol (Oxf). 1982;17:213-22.

29. Arafah BM, Harrington JF, Madhoun ZT, Selman WR. Improvement of pituitary function after surgical decompression for pituitary tumor apoplexy. J Clin Endocrinol Metab. 1990;71: 323-8.

30. Powell M. Recovery of vision following trans-sphenoidal surgery for pituitary adenomas. Br J Neurosurg. 1995;9:367-73.

31. Gnanalingham KK, Bhattacharjee S, Pennington R, Mendoza J, Ng N. The time course of visual field recovery following transphenoidal surgery for pituitary adenomas: predictive factors for a good outcome. J Neurol Neurosurg Psychiatry. 2005;76:415-9.

32. Comtois R, Beauregard H, Somma M, Serri O, Aris-Jilwan N, Hardy J. The clinical and endocrine outcome to trans-sphenoidal microsurgery of nonsecreting pituitary adenomas. Cancer. 1991;68(4):860-6.

33. Erfurth EM, Bülow B, Nordström CH, Mikoczy Z, Hagmar L, Strömberg $U$. Doubled mortality rate in irradiated patients reoperated for regrowth of a macroadenoma of the pituitary gland. Eur J Endocrinol. 2004;150:497-502.

34. Bates AS, Bullivant B, Sheppard MC, Stewart. PM. Life expectancy following surgery for pituitary tumors. Clin Endocrinol. 1999;50:315-9.

35. Semple PL, Laws ER Jr. Complications in a contemporary series of patients who underwent transsphenoidal surgery for Cushing's disease. J Neurosurg. 1999;91:175-9.

36. Swearingen B, Barker 2nd FG, Katznelson L, Biller BM, Grinspoon S, Klibanski A, et al. Long-term mortality after transsphenoidal surgery and adjunctive therapy for acromegaly. J Clin Endocrinol Metab. 1998;83:3419-26.

37. Barker FG, Klibanski A, Swearingen B. Transsphenoidal surgery for pituitary tumors in the United States, 1996-2000: mortality, morbidity, and the effects of hospital and surgeon volume. J Clin Endocrinol Metab. 2003;88(10):4709-19.

38. Wilson, JD, Foster DW, Kronenberg, HM, Larsen PR. William's Textbook of Endocrinology 9. ed. Philadelphia, USA: Saunders.

39. Harris PE. Biochemical markers for clinically non-functioning pituitary tumours. Clin Endocrinol. 1998;49:163-4.

40. Bradley KJ, Wass JAH, Turner HE. Non-functioning pituitary adenomas with positive immunoreactivity for ACTH behave more aggressively than ACTH immunonegative tumours but do not recur more frequently. Clin Endocrinol. 2003;58:59-64. 